\title{
Effect of starch binder on charcoal briquette properties
}

\author{
Gabriel Borowski*, Witold Stęniewski, and Katarzyna Wójcik-Oliveira \\ Faculty of Environmental Engineering, Lublin University of Technology, Nadbystrzycka 40b, 20-618 Lublin, Poland
}

Received April 19, 2017; accepted September 25, 2017

\begin{abstract}
The paper shows the results of a study on the effect of starch binder on the mechanical, physical and burning properties of charcoal briquettes. Two types of binders were repeatedly used to make briquettes of native wheat starch and modified wheat starch, at $8 \%$ of the whole. Briquetting was performed in a roller press unit, and pillow-shaped briquettes were made. The moisture of the mixed material ranged from 28 to $32 \%$. The product, whether the former or the latter, was characterized by very good mechanical properties and satisfactory physical properties. Moreover, the type of starch binder had no effect on toughness, calorific heating value, volatiles, fixed carbon content and ash content. However, the combustion test showed quite different burning properties. As briquettes should have short firing up time and lower smokiness, as well as high maximum temperature and long burning time, we have concluded that briquettes with native wheat starch as a binder are more appropriate for burning in the grill.

Keyw ord s: charcoal briquette, starch binder, burning
\end{abstract}

\section{INTRODUCTION}

Charcoal fuel has many attractive features: it contains almost no sulfur or mercury and is low in nitrogen and ash, in addition, it is easy to store and handle (Antal and Grønli, 2003). Further technical and economic aspects of fine coal and charcoal briquettes have been evaluated because of the binder and briquetting parameters. Briquetting pressure and dwell time have a weak impact, while binder type and curing conditions exert the greatest influence on briquettes quality (Borowski and Hycnar, 2013; Taulbee et al., 2009). What is more, mechanical properties increase with time of curing at room temperature of carbonized-coal briquettes (Blesa et al., 2003).

\footnotetext{
*Corresponding author e-mail: g.borowski@pollub.pl
}

Binders such as molasses, starch, tar, etc. are added to produce fuel briquettes, and the addition of starch binder, as well as gum Arabic binder improves the caloric value of biofuel briquettes (Zakari et al., 2013). Physical properties such as density, compressive strength and impact resistance index of briquettes also show significant improvement because of binders (Sen et al., 2016). Further additives are inorganic fillers which delay the heat release of the burning briquette, and ignition enhancers, which promote greater combustibility. Charcoal briquettes are promoted as substitutes for natural coal, petroleum coke or lignite. Still, the advantages of charcoal fuel depend on important factors: low sulphur content, high carbon to ash ratio, relatively few and nonreactive inorganic impurities, specific pore structure with large surface area, good reduction ability, almost smokeless emissions (Emrich, 1985). The disadvantages of charcoal fuel are clearly seen when compared to liquefied petroleum gas (LPG) fuel. The charcoal grilling footprint of $\mathrm{CO}_{2}$ is almost three times larger than for LPG combustion. In addition, LPG is radically more efficient than charcoal in its production, and considerably more efficient in cooking. However, the use of LPG requires a heavier and more complicated grill (Johnson, 2009).

In using briquettes, odour and visible smoke are not wanted. These effects can be induced by the use of certain binders, so briquettes should be subjected to a burning test. Briquettes also must not be affected by fermentation aggression for at least for 18 months (Emrich, 1985). Charcoal briquettes are mostly used for cooking, heating, barbequing and camping in many countries (Sotannde, 2010).

(C) 2017 Institute of Agrophysics, Polish Academy of Sciences 
The aim of this study was to examine the effect of two types of starch binders on the mechanical, physical and burning properties of charcoal briquettes.

\section{MATERIALS AND METHODS}

In the experiment, two types of briquettes were made, with native wheat starch (T1), and modified wheat starch (T2) used as binder.

Native wheat starch is a carbohydrate composed of glucose molecules, extracted directly from plants and untreated. It is poorly resistant to physical conditions. Modified wheat starch is produced from native starch through physical, enzymatic and chemical transformations. These modifications mainly improve the rheological properties, which increases the stability of the emulsions and suspensions. They also reduce adhesion. This favors uniform distribution of starch during mixing. The most common way to modify wheat starch is by creating structural cross-links through the introduction of di- or polyfunctional compounds, e.g. adipic acid or sodium trimethaphosphate. The cross-linking process has a major impact on the increased thermal resistance of the modified starches as compared to native. Manufacturers of starch preparations offer products that vary in the grade of cross-linking and resulting specific properties, hence their use as a briquetting binder requires laboratory testing.

The lump charcoal used in our research was produced from wood sourced in Europe. The material was first ground in a mill to a fraction below $2.0 \mathrm{~mm}$. The charcoal powder was then mixed with the starch binder. The binder held a dry mass share of $8 \%$ of the mixture. The grinding and mixing of the material was performed as described in the Polish standard PN-G-04502:2014-11. Moisture of the material before briquetting was $28-32 \%$. The moisture content of material was determined according to the Polish standard PN-ISO 589:2006. Density was assessed by direct measurements of the mass and volume of briquettes and dividing mass by volume.

Briquetting was conducted in a roller press unit with a horizontal roller system. Herein, pillow-shaped briquettes were made in forming matrices. The briquettes were then directed to the drying tunnel, where moisture was reduced below $6 \%$. Next, the toughness of the briquettes was determined using the gravitational drop test and an axial compression test, as described by Borowski and Hycnar (2013).

Briquette samples were dropped three times from a height of $2.0 \mathrm{~m}$ onto a metal base, then the percentage Impact Strength Index was calculated. In such work, minimum impact strength index should be at least $90 \%$. Axial compression test involved crushing a briquette placed between flat surfaces of a testing machine, until its structure failed. The lower compressive strength value should be above 1.0 MPa (Borowski and Hycnar, 2013).
Temperature measurements were made while the sample underwent combustion as performed on a test stand equipped with a covered grill grate, mounted thermocouple and smoke outlet. Combustion tests were carried out for $2 \mathrm{~kg}$ portions of briquettes, which were placed on the grid along with a fire-kindling cartridge. After completion of the firing, the glowing briquettes were placed in two separate cages. The burning process was continued with the lid closed and with constant measurement of the temperature until such was reduced to below $180^{\circ} \mathrm{C}$.

The calorific value of the test briquettes was determined by employing the calorimetric method. This involves ascertaining the heat of combustion of the test sample at a constant volume of bomb calorimeter, and is calibrated via the standard test combustion of benzoic acid. The calculation is based on the indicated heat of combustion decreased by heat of vaporization of the water separated out during the fuel combustion.

The ash content was determined by the method of heating the test sample to a constant temperature within a specific time interval. The resulting mass of ash residue was used to calculate the ash content. The volatile content was determined by heating the sample in a closed pan without air, and was calculated from the difference between the total weight loss of the solid fuel sample, and the weight loss due to moisture loss. The fixed carbon content was obtained by subtracting the sum of ash, moisture and volatile matter from 100, wherein all values are on the same moisture reference base. The burn-up factor was determined as the share of burned fuel relative to total dry matter.

\section{RESULTS AND DISCUSSION}

The results of the physical and mechanical properties of charcoal briquettes are presented in Table 1 .

The tested charcoal briquettes were characterized by having very good mechanical properties. Whether T1 or $\mathrm{T} 2$, the value of impact strength index was 98.8 , while the value of compressive strength reached 24.5. These figures were higher, compared to the values reported in the literature of charcoal briquettes (Antal and Grønli, 2003; Sen et al., 2016).

The higher heating value (HHV) value of the briquette was about $26.5 \mathrm{MJ} \mathrm{kg}^{-1}$. Comparing the results, these results are in the middle of the range established by other investigators. When pine needle briquettes were burned, $\mathrm{HHV}=21.2 \mathrm{MJ} \mathrm{kg}^{-1}$ was noticed (Pandey and Dhakal, 2013). When wood residue briquettes were combusted, $\mathrm{HHV}=32.5 \mathrm{MJ} \mathrm{kg}^{-1}$ (Sotannde et al., 2010). Our results are a slightly lower, compared to the HHV of coal briquettes, being from 24.5 to $33.8 \mathrm{MJ} \mathrm{kg}^{-1}$ (Taulbee et al., 2009).

We found the content of volatiles to be within the range $25-30 \%$, while the share of ashes from burning of either $\mathrm{T} 1$ or $\mathrm{T} 2$ briquettes constituted $5-10 \%$. Pandey and Dhakal (2013) obtained very similar results. We saw a fixed carbon content (FCC) of $60-68 \%$. Other authors found a higher 
Table 1. Physical and mechanical properties of the charcoal briquettes

\begin{tabular}{lc}
\hline Specification & Results \\
\hline Particles size of the charcoal $(\mathrm{mm})$ & $0.05-2.0$ \\
Weight of $1 \mathrm{pcs}(\mathrm{g})$ & 42.5 \\
Dimensions $\mathrm{W} \times \mathrm{H} \times \mathrm{D}(\mathrm{mm})$ & $60 \times 50 \times 30$ \\
Density $\left(\mathrm{kg} \mathrm{m}^{-3}\right)$ & 700 \\
Higher heating value $\left(\mathrm{MJ} \mathrm{kg}^{-1}\right)$ & 26.5 \\
Lower heating value $\left.(\mathrm{MJ} \mathrm{kg})^{-1}\right)$ & 26.0 \\
Content of volatiles $(\%)$ & $25-30$ \\
Fixed carbon content $(\%)$ & $60-68$ \\
Ash content $(\%)$ & $5.0-10.0$ \\
Impact strength index $(\%)$ & 98.8 \\
Compressive strength $(\mathrm{MPa})$ & 24.5 \\
\hline
\end{tabular}

Table 2. Effect of starch binder on the burning of charcoal briquettes

\begin{tabular}{lcc}
\hline & \multicolumn{2}{c}{ Wheat starch } \\
\cline { 2 - 3 } Specification & native (T1) & modified (T2) \\
\hline Time of smoke (min:sec) & $9: 34$ & $10: 45$ \\
Firing up time (min:sec) & $13: 53$ & $16: 21$ \\
$\begin{array}{l}\text { Burning time of temperature } \\
\text { above } 180^{\circ} \mathrm{C}(\mathrm{min})\end{array}$ & 264 & 299 \\
$\begin{array}{l}\text { The maximum temperature } \\
\left({ }^{\circ} \mathrm{C}\right)\end{array}$ & 307 & 285 \\
Burn-up factor $(\%)$ & 97 & 95 \\
\hline
\end{tabular}

value of FCC of approx. 73\%, but in some works, a relatively low HHV value was found for the charcoal briquettes, which was about $20.8 \mathrm{MJ} \mathrm{kg}^{-1}$ (Onchieku et al., 2012).

The effect of two binders on the combustion properties of briquettes is shown in Table 2. As seen, the combustion time of T1 briquettes was shorter than of T2 briquettes, as well as was the time of intense smoke. There was also shorter time of burning to temperatures above $180^{\circ} \mathrm{C}$ (264 min versus $299 \mathrm{~min}$ ). Moreover, the maximum temperature of burning of T1 briquettes reached $307^{\circ} \mathrm{C}$, which is higher than that of T2. The burn-up factor is also higher for briquettes comprised of native wheat starch binder. The temperature curve for the burning test of T1 and T2 briquettes is presented in Fig. 1.

In the combustion of the $\mathrm{T} 2$ briquette, a rapid temperature drop in the first stage of the process was observed. This lasted less than two hours. In a subsequent step, the temperature was maintained at a stable level above $200^{\circ} \mathrm{C}$. This lasted two hours. While burning the T1 briquettes, a stable temperature of about $300^{\circ} \mathrm{C}$ was observed in the first stage of the process. However, a rapid descent of temperature to a value below the limit of $180^{\circ} \mathrm{C}$ was noticed in the next two hours.

In firing up both types of briquettes, intense dark gray smoke was first observed. This persisted until the temperature rose to about $200^{\circ} \mathrm{C}$. After this, the smoke color turns white until the temperature increases to $300^{\circ} \mathrm{C}$. In the subsequent step of burning, minor amounts of smoke with a slight blue tint were observed. It should be noted that more smoke was observed during the firing and burning of $\mathrm{T} 2$ briquettes. This effect may be due to higher content of gluten and protein in modified starch.

The burning properties of charcoal as presented by Onchieku et al. (2012) show quite similar results. Herein, combustion time ranged from 6 to $15 \mathrm{~min}$. They also found that their charcoal samples burnt almost without smoking, showing a blue glowing flame. In addition, no sparks were produced and no smell was released.

Further testing of starch binders is planned, especially of potato starch and rye starch. The effect of the selected binder would be to improve briquette properties such as reducing the consumption of starch, increasing the efficiency

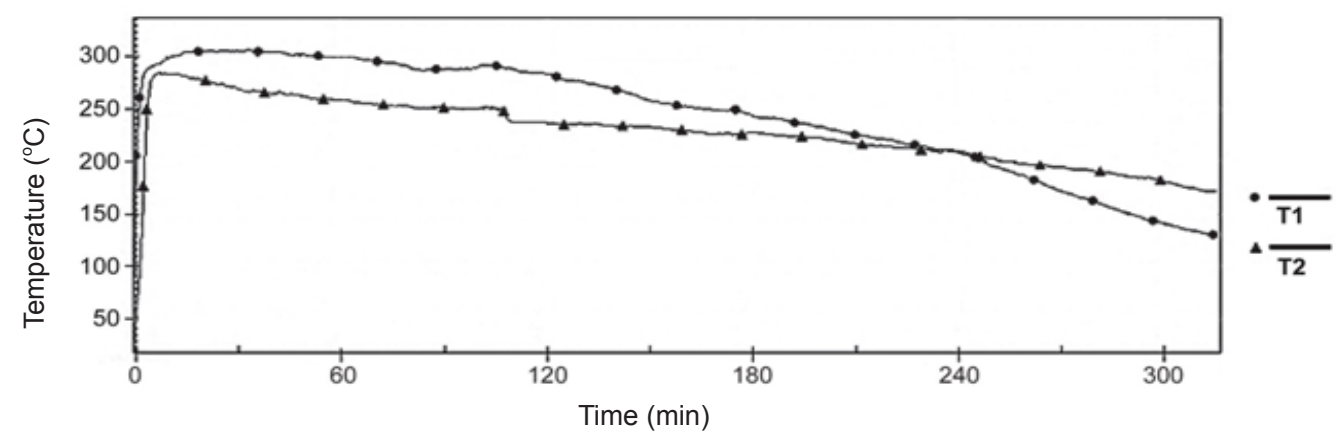

Fig. 1. Temperature curve in the combustion of charcoal briquettes: $\mathrm{T} 1$ - binder of native wheat starch, T2 - binder of modified wheat starch. 
of the drying, shortening the firing up time, reducing smoke output, and extending the burning time of briquettes on the grill.

\section{CONCLUSIONS}

1. The mechanical properties of the test charcoal briquettes depend on the binder share. Both types of briquettes were strong enough for storage, loading and transport, regardless of the binder used.

2. The physical properties of the test briquettes were also satisfactory, regardless of the type of binder. The results show adequacy for use in barbecues.

3. Burning properties were quite different for the two types of briquettes and binders used in the tests. These differed in firing up time, burning time, temperature distribution and smoke intensity. Briquettes with native wheat starch binder seemed to be more appropriate for burning in the grill.

Conflict of interest: The Authors do not declare conflict of interest.

\section{REFERENCES}

Antal M.J. and Grønli M., 2003. The art, science, and technology of charcoal production. Industrial Eng. Chemistry Res., 42(8), 1619-1640. DOI: 10.1021/ie0207919

Blesa M.J., Miranda J.L., Izquierdo M.T., and Moliner R., 2003. Curing time effect on mechanical strength of smokeless fuel briquettes. Fuel Proc. Technol., 80(2), 155-167. DOI: 10.1016/S0378-3820(02)00243-6

Borowski G. and Hycnar J.J., 2013. Utilization of fine coal waste as a fuel briquettes. Int. J. Coal Preparation Utilization, 33(4), 194-204. DOI: 10.1080/19392699.2013. 787993 .
Emrich W., 1985. Handbook of charcoal making. The traditional and industrial methods. Solar Energy R\&D in the Eutropean Community, Ser. E: Energy from Biomass, 7, SpringerScience+Business Media B.V.

Johnson E., 2009. Charcoal versus LPG grilling: A carbon-footprint comparison. Environmental Impact Assessment Review, 29, 370-378.

Onchieku J.M., Chikamai B.N., and Rao M.S., 2012. Optimum parameters for the formulation of charcoal briquettes using bagasse and clay as binder. European J. Sustainable Develop., 1(3), 477-492.

PN-G-04502:2014-11. Polish standard 'Coal and lignite Sampling and preparation of laboratory samples - Basic methods'.

PN-ISO 589:2006. Polish standard 'Coal - Determination of total moisture'.

Pandey S. and Dhakal R.P., 2013. Pine needle briquettes: A renewable source of energy. Int. J. Energy Sci., 3(3), 254-260.

Sen R., Wiwatpanyaporn S., and Annachhatre A.P., 2016. Influence of binders on physical properties of fuel briquettes produced from cassava rhizome waste. Int. J. Environ. Waste Manag., 17(2), 158-175. DOI: 10.1504/ IJEWM.2016.076750

Sotannde O.A., Oluyege A.O., and Abah G.B., 2010. Physical and combustion properties of charcoal briquettes from neem wood residues. Int. Agrophys., 24(2), 189-194.

Taulbee D., Patil D.P., Honaker R.Q., and Parekh B.K., 2009. Briquetting of coal fines and sawdust Part I: Binder and briquetting-parameters evaluations. Int. J. Coal Preparation Utilization, 29(1), 1-22. DOI: 10.1080/19392690802628705

Zakari I.Y., Ismaila A., Sadiq U., and Nasiru R., 2013. Investigation on the effects of addition of binder and particle size on the high calorific value of solid biofuel briquettes. J. Natural Sci. Res., 3(12), 30-34. 